\title{
Grazing season and forage type influence goat milk composition and rennet coagulation properties
}

\author{
R. A. Inglingstad, ${ }^{\star 1}$ H. Steinshamn,† B. S. Dagnachew,‡ B. Valenti,§ A. Criscione,§ E. O. Rukke, ${ }^{*}$ \\ T. G. Devold, ${ }^{*}$ S. B. Skeie, ${ }^{*}$ and G. E. Vegarud* \\ *Department of Chemistry, Biotechnology and Food Science, Norwegian University of Life Sciences, PO Box 5003, NO-1432 Ås, Norway \\ †Norwegian Institute for Agricultural and Environmental Research (Bioforsk), Organic Food and Farming Division, Gunnars veg 6 , \\ NO-6630 Tingvoll, Norway \\ ‡Department of Animal and Aquacultural Sciences, Norwegian University of Life Sciences, Box 5003, NO-1432 Ås, Norway \\ $\S$ Department of Agricultural and Food Sciences (DISPA), University of Catania, via Valdisavoia 5, 95123 Catania, Italy
}

\section{ABSTRACT}

Two different types of pasture (cultivated and rangeland) and 2 different hay qualities (high and low quality) were examined for their effects on goat milk composition and rennet coagulation properties. Furthermore, the effect of dietary treatments in both the early and late grazing season was studied. As lactation stage is known to influence milk composition, the goats in the early and late grazing season were in the same lactation stage at the start of the experiment. The milk composition was influenced both by dietary treatment and season. Milk from goats on pasture was superior to those on hay by containing a higher content of protein and casein, and the goats on cultivated pasture had the highest milk yield. Casein composition was significantly influenced by forage treatment. Goats grazing on cultivated pasture had higher contents of $\alpha_{\mathrm{s} 1}$-casein and also of $\kappa$-casein compared with the other treatments, whereas goats grazing on rangeland had the highest content of $\beta$-casein. Factors such as milk yield, casein micelle size, $\alpha_{\mathrm{s} 2}$-casein, and calcium content were reduced in late compared with early season. More favorable rennet coagulation properties were achieved in milk from the early grazing season, with shorter firming time and higher curd firmness compared with milk from the late grazing season, but the firming time and curd firmness were not prominently influenced by forage treatment. The content of $\alpha_{\mathrm{s}^{2}}$-casein and calcium in the milk affected the firming time and the curd firmness positively. The influence of season and forage treatment on especially milk yield, casein content, and rennet coagulation properties is of economic importance for both the dairy industry and goat milk farmers.

Key words: goat milk, milk rennet coagulation properties, individual casein composition, pasture

Received September 30, 2013.

Accepted February 21, 2014.

${ }^{1}$ Corresponding author: raaboe@nmbu.no

\section{INTRODUCTION}

Norway has a long tradition of goat milk production. Most of the milk from about 40,000 dairy goats is used for production of the traditional brown whey cheese (Brunost). The demand for brown whey cheese among Norwegian consumers is declining, and the interest in rennet- and acid-coagulated cheeses is increasing among the dairy industry and consumers. However, production of these cheeses requires a milk of a more stable and higher quality than milk used for brown whey cheese. Quality cheese milk has high DM content (casein and fat is most important), low SCC, and low susceptibility to excessive lipolysis, maintaining a low content of FFA. In addition, the ability to clot by the action of rennet and achievement of a firm curd are important factors in cheese manufacture (Skeie, 2010).

Previous studies have shown that the population of Norwegian goats has a high frequency of animals with low or no synthesis of $\alpha_{\mathrm{s} 1}$-CN (Devold et al., 2011). This is caused by an extremely high frequency (0.73) of a defective allele with a single nucleotide deletion in exon 12 of the gene encoding $\alpha_{\mathrm{s}^{-}} \mathrm{CN}$ (CSN1S1; Hayes et al., 2006; Dagnachew et al., 2011). Until now, Norwegian dairy goats are the only breed known to carry this deletion. In addition to low or no expression of $\alpha_{s 1}$-CN in the milk, this deletion correlates with a reduced content of protein, fat, and lactose; a high content of FFA; and tart and rancid flavor (Dagnachew et al., 2011). Milk from Norwegian goats shows poor rennet coagulation properties and sensory quality in periods of the year. The milk-quality challenges are more pronounced during the grazing season (Eknæs and Skeie, 2006). Traditionally, goat milk production is seasonal, with kidding in winter and early spring and with peak milk production during the summer grazing season. During the grazing season, the goats graze to a large extent on natural unimproved grassland or free range in forest and mountain grasslands. The quality of these pastures is variable and declines with forage production during the grazing season (Lunnan and Todnem, 2011). The 
decline in forage and milk quality coincides with advanced lactation stage, another factor associated with increased FFA content in goat milk (Chilliard et al., 2003). Thus, the effects of the grazing season and the lactation stage on milk quality may be confounded. The high degree of polymorphism at the $\alpha_{\mathrm{s} 1}$-CN locus (for review, see Marletta et al., 2007) is known to affect both casein content and rennet coagulation properties (Clark and Sherbon, 2000; Devold et al., 2011). However, few studies exist focusing on the effect of forage quality on rennet coagulation properties and protein quality (i.e., the casein content and composition of individual caseins in milk from dairy goats).

Hence, the objective of this work was to study the effects of grazing season (early and late), forage type [hay (high- and low-quality hay)], and pasture (cultivated and rangeland) on milk composition and rennet coagulation properties. To separate the effects of these factors from the effect of lactation, all goats were in the same lactation stage at the start of the feeding experiment.

\section{MATERIALS AND METHODS}

\section{Experimental Design and Diets}

The experiment comprised 80 Norwegian dairy goats, located at Gibostad research farm, Norway $\left(69^{\circ} 21.397^{\prime} \mathrm{N}\right.$, $\left.17^{\circ} 56.319 \mathrm{E}\right)$. A simplified overview of the experimental design is shown in Figure 1. The goats were genotyped according to Hayes et al. (2006) with respect to the deletion in exon 12 the gene encoding $\alpha_{\mathrm{s} 1}$-CN (CSN1S1). The individuals were blocked according to lactation number $(5$ groups: $1=$ first lactation, $2=$ second lactation, $3=$ third lactation, $4=$ fourth lactation, and 5 $=$ more than 4 lactations) and genotype [homozygous (E12-00) or nonhomozygous (E12-01/E12-11) for the deletion in exon 12], and the goats within each of these blocks were further randomly divided into 2 groups [early (EGS) and late (LGS) grazing season]. The goats in EGS were mated approximately $8 \mathrm{wk}$ before those in LGS, and the average kidding date was February $2(\mathrm{SD}=9 \mathrm{~d})$ and April $1(\mathrm{SD}=12 \mathrm{~d})$ for the EGS and LGS group, respectively. From kidding until the start of the grazing season (June 28, 2010) the goats received the same diet: silage fed ad libitum and $1.1 \mathrm{~kg}$ of concentrate $/ \mathrm{d}$ per goat. The concentrate was produced for this experiment by Felleskjøpet Agri (Storsteinnes, Norway) and was a mixture with the following ingredients $(\mathrm{g} / \mathrm{kg})$ : barley (278), oat (263), wheat bran (159), sugar cane molasses (65), sugar beet pulp (60), extracted soybean meal (46), oil seed (41), SoyPass (Denofa AS, Fredrikstad, Norway, WI; 34), limestone (19), and other minerals and vitamins (35).
At approximately 130 DIM (June 28 and August 16 for the EGS and LGS group, respectively), the goats were randomly assigned to 4 homogenous treatment groups. The treatment groups were balanced for genotype and lactation number and each consisted of 10 goats. The 4 treatments were cultivated pasture (PC), rangeland pasture $(\mathbf{P R})$, high-quality hay $(\mathbf{H H})$, and low-quality hay (HL). The chemical composition for the 2 hay qualities ( $\mathrm{HH}$ and $\mathrm{HL}$ ) and concentrate used in the experiment and of the silage fed indoors from kidding to the start of the grazing season are given in Table 1 . The goats on hay were kept indoors in pens and the hay was fed ad libitum, allowing $10 \%$ refusals. The goats on pasture grazed day and night. The PC was a ley (2.1 ha in area) in its first production year dominated by Phleum pratense and Festuca pratensis. The daily allowance was on average $13 \mathrm{~kg}$ of DM/goat. The PR was approximately 300 ha with the following vegetation types (\% of land area): blueberry-birch woodland (41), fen (22), meadow-birch forest (21), lichen/heather-birch woodland (6), wet woodland (4), natural grassland (4), and spruce woodland (2). Dominating species were birch (Betula pubescens), bilberries (Vaccinium myrtillus), Swedish cornel (Cornus suecica), wavy hair-grass (Avenella flexuosa), and sweet vernal grass (Anthoxanthum odoratum).

The LGS group grazed together with the PR group of the EGS goats until August 16, 2010. The forage treatment periods lasted for 3 wk. All goats during the forage treatment period were supplemented with the same concentrate mixture as fed during the indoor period at a rate of $0.9 \mathrm{~kg} / \mathrm{d}$ and the concentrate was given during milking twice daily.

To summarize, the design applied was a $2 \times 4$ factorial with season (EGS and LGS) as one factor and forage type (PC, PR, HH, and HL) as the other factor. The 10 goats in each treatment (PC, PR, HH, and HL) were randomly divided into 2 groups (pens) with 5 goats, accounting for genotype and lactation number. In the 2 hay treatments, the 5 goats in each group within treatment were kept indoors in 2 separate pens, whereas the goats within each pasture treatment grazed together. The procedures in the experiment were according to the regulations set by the Norwegian Animal Research Authority (Oslo, Norway).

\section{Feed Intake, Feed Sampling, and Analysis}

Feed intake on pasture was estimated by the use of the $n$-alkane technique (Mayes et al., 1986) and is reported for the current experiment by Steinshamn et al. (2014). Procedures for sampling and preparation of samples of grazed plants, hay, and concentrate are also described by Steinshamn et al. (2014). The chemical composition 

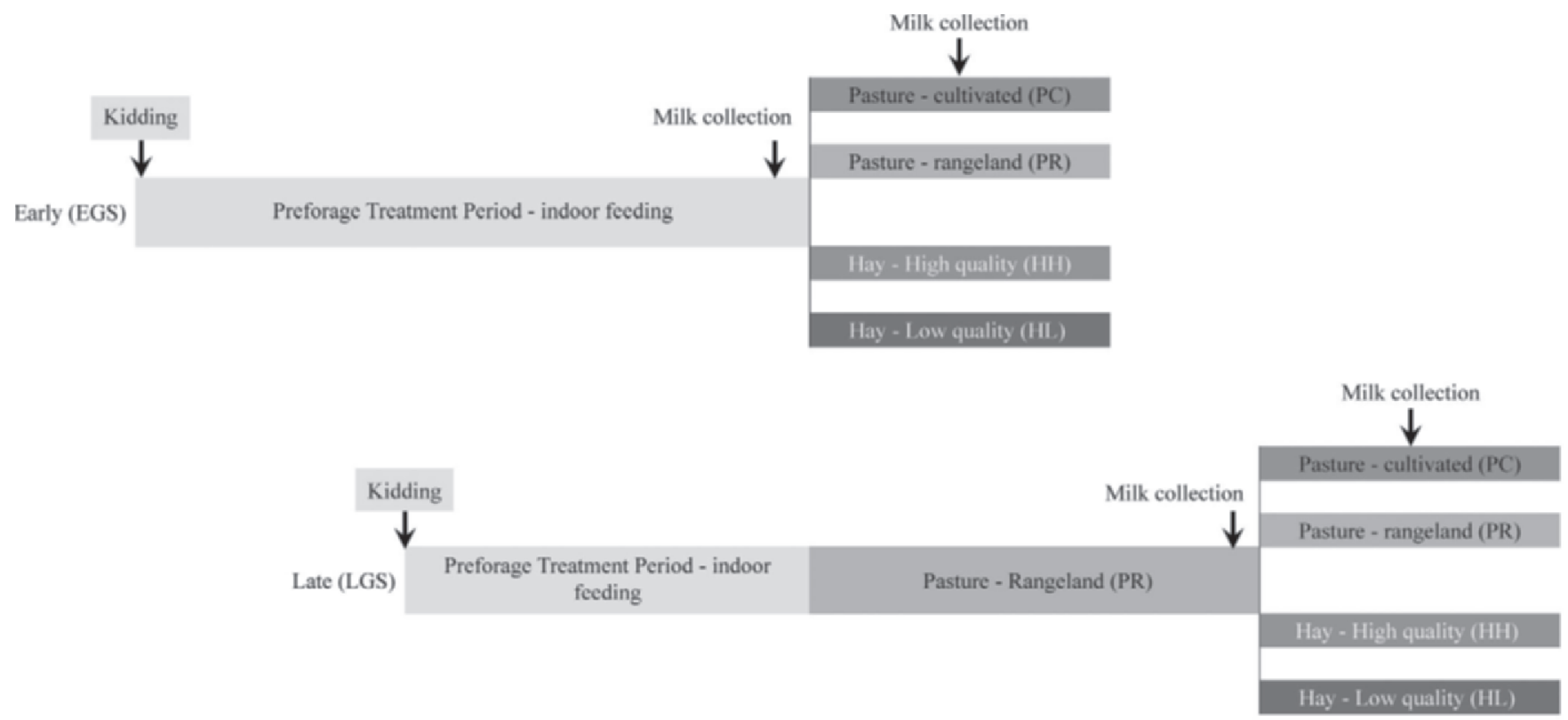

January

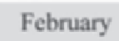

March

April

May

June

July

August

September

Figure 1. Experimental design. Eighty goats were divided into 2 groups: early (EGS) and late (LGS) grazing season, with 8 wk difference in kidding time. At 130 DIM, they were further allocated into 4 dietary treatment groups: low-quality hay (HL), high-quality hay (HH), rangeland pasture (PR), and cultivated pasture (PC). The arrows indicate when milk yield was measured and milk samples for chemical analysis were collected.

of feed and pasture samples were analyzed at the Dairy One Inc. Forage Testing Laboratory (Ithaca, NY) with wet chemical procedures. Crude protein content was determined using AOAC method 990.03 and crude fat by AOAC method 2003.05 (AOAC, 1990). Heat-stable, $\alpha$-amylase-treated, sodium sulfite NDF was determined using an Ankom fiber analyzer (Ankom Technology Corp., Fairport, NY) based on procedures described by Van Soest et al. (1991). Digestibility of DM and $\mathrm{NDF}$ was determined in vitro after incubation for $48 \mathrm{~h}$ using the Ankom DaisyII filter bag technique (Ankom Technology Corp., Macedon, NY). The $\mathrm{NE}_{\mathrm{L}} 3 \times$ maintenance was predicted from total digestible nutrients according to the NRC (2001). Daily intake of hay per goat per pen was calculated as kilograms of DM offered per pen - kilograms of DM refused per pen divided by the number of goats per pen. Feed quality of consumed hay was calculated as the difference between quantity of the quality parameter offered (e.g., CP) and quantity of the quality parameter refused divided by the DM consumed. The quality of the herbage consumed on pasture was calculated as the weighted mean of the nutritive value of each botanical component of the diet. Least-squares optimization using available alkane and alcohols was used to obtain estimates of the botanical composition of the diet. The feed quality of the forages as consumed and of concentrate is presented in Table 1 .

\section{Milk Sampling and Analysis of Milk Composition}

Milk samples were collected twice during each grazing period (EGS and LGS): 1 wk before the goats were allocated to the forage treatments (preforage treatment period) and $2 \mathrm{wk}$ after onset of the dietary treatment (forage experimental period; Figure 1). The goats were milked twice daily (0630 and $1600 \mathrm{~h}$ ) and milk yield recorded. Samples from 4 subsequent milkings (2 d) were pooled to have 1 milk sample from each goat. Samples for analysis of casein composition and minerals were stored at $-20^{\circ} \mathrm{C}$, and samples for analysis of casein micelle size (preserved with sodium azide) were stored in room temperature (1 night), whereas the rest of the samples were stored at $4^{\circ} \mathrm{C}$ until analysis.

Milk Composition (Routine Analysis). Milk samples were preserved with bronopol (2-bromo2-nitropropane-1,3-diol; D \& F Control Systems Inc., San Ramon, CA) and analyzed for fat, protein, lactose, urea, and SCC by Fourier-transform infrared spectroscopy (MilkoScan CombiFoss 6500; Foss, Hillerød, Denmark).

Milk Fat Removal. Before analysis of protein and casein micelle size, the milk was skimmed. The samples were centrifuged at $2,000 \times g$ for $20 \mathrm{~min}$ at $25^{\circ} \mathrm{C}$ and then the milk fat was crystallized at $-20^{\circ} \mathrm{C}$ for $20 \mathrm{~min}$ before the milk fat was removed by a spatula. 

Total nitrogen (TN), noncasein nitrogen (NCN), and NPN contents of skim milk samples were measured by a Kjeltec 8400 analyzer (Foss) according to Aschaffenburg and Drewry (1959) modified by Devold et al. (2011). The NCN fraction was prepared from $2 \mathrm{~mL}$ of milk and the casein fraction was precipitated at $\mathrm{pH} 4.2$ instead of $\mathrm{pH} 4.6$ using a buffer of $1 M$ acetic acid and $1 \mathrm{M}$ sodium acetate [37:3; buffers prepared according to Pearse (1980)]. All samples were run in triplicate. The calculations used for total protein (TP) percentage and casein percentage were as follows:

$$
\begin{aligned}
\text { Total protein }(\mathrm{TP}) & =(\mathrm{TN}-\mathrm{NPN}) \times 6.38 ; \\
\text { Whey protein }(\mathrm{WP}) & =(\mathrm{NCN}-\mathrm{NPN}) \times 6.38 ; \\
\text { Casein } & =\mathrm{TP}-\mathrm{WP} .
\end{aligned}
$$

Quantification of Individual Caseins. To quantify individual caseins, a combined approach of cation-exchange chromatography and capillary zone electrophoresis was followed. Cation-exchange chromatography was implemented to obtain protein standards from the isoelectric casein of a genotyped goat that was homozygous for strong alleles at $\alpha_{\mathrm{s}^{-}}, \alpha_{\mathrm{s} 2^{-}}, \beta-$, and $\kappa-\mathrm{CN}$. Cation-exchange chromatography was performed on an ÄKTA purifier (GE Healthcare, Freiburg, Germany) equipped with a HiLoad 26/10 SP Sepharose HP column (GE Healthcare, Uppsala, Sweden). The analysis was performed according to Gómez-Ruiz et al. (2004) with the following modifications: the 4 caseins were obtained by a unique separation with buffer A [6 $M$ urea, $0.02 M \mathrm{Na}$ acetate, and $64 \mu M$ dithiothreitol (DTT)] adjusted to $\mathrm{pH} 4$ and buffer $\mathrm{B}$, which had the same composition and $\mathrm{pH}$, but with the addition of $1 M$ $\mathrm{NaCl}$. Casein fractions were eluted with the following gradient: $0 \% \mathrm{~B}$ for 0.33 of the column volume $(\mathbf{C V o l})$, $2.5 \%$ B for $0.02 \mathrm{CVol}, 7.5 \%$ B for $1.4 \mathrm{CVol}, 16 \% \mathrm{~B}$ for 1 CVol, $18 \%$ B for 3.5 CVol, $32 \%$ B for $1.25 \mathrm{CVol}, 32 \%$ B for $1.5 \mathrm{CVol}$, and $40 \% \mathrm{~B}$ for $2 \mathrm{CVol}$. The flow rate was $5 \mathrm{~mL} / \mathrm{min}$ and the absorbance was recorded at $280 \mathrm{~nm}$. Peaks of individual caseins were collected by a fraction collector and lyophilized after dialysis.

Capillary electrophoresis analysis was performed by use of a Beckman P/ACE MDQ system controlled by 32 Karat Software (version 8.0; Beckman Instruments Inc., Fullerton, CA). The instrument was equipped with a UV detector set at $214 \mathrm{~nm}$. Casein separation was achieved according to the method described by Valenti et al. (2012). Calibration curves for quantification of the individual caseins were performed, taking into account the expected range of variation for each casein fraction (Gómez-Ruiz et al., 2004). 
$\boldsymbol{p} \boldsymbol{H}$. The $\mathrm{pH}$ of milk $\left(20^{\circ} \mathrm{C}\right)$ was measured using a $\mathrm{pH}$ meter (PHM 61; Radiometer, Copenhagen, Denmark) coupled to a pH electrode (pHC2005; Radiometer Analytical SAS, Villeurbanne Cedex, France).

Mean Size of Casein Micelles. The mean size of casein micelles was measured by photon correlation spectroscopy using the Zetasizer 3000 HS particle size analyzer (Malvern Instruments Ltd., Malvern, UK) according to the protocol of Devold et al. (2000). Before size analysis, milk samples were skimmed and diluted in simulated milk ultrafiltrate (Jenness and Koops, 1962) that had been filtered through a $0.2-\mu \mathrm{m}$ filter (Millipore Corp., Bedford, MA).

Mineral Composition. The content of total Ca, P, $\mathrm{Mg}$, and $\mathrm{K}$ was measured by inductive coupled plasma optical emission spectrometry (PerkinElmer optima 5300 DV; Perkin Elmer Inc., Shelton, CT). The samples were decomposed in concentrated, subboiled nitric acid at $250^{\circ} \mathrm{C}$ in an UltraCLAVE microwave digestion system (UltraCLAVE III; Milestone Inc., Shelton, CT) and diluted 1:10 in concentrated nitric acid before analysis.

Rennet Coagulation Properties. Rennet clotting properties of individual milks were measured by a Formagraph instrument (Lattodinamografo; Foss Italia SpA, Padova, Italy) according to the method described by McMahon and Brown (1982). The milk was pasteurized (at $63^{\circ} \mathrm{C}$ for $30 \mathrm{~min}$ ) before cooling to room temperature. The milk $(10 \mathrm{~mL})$ was incubated at $32^{\circ} \mathrm{C}$ for $30 \mathrm{~min}$ in the sample cuvette and then $200 \mu \mathrm{L}$ of rennet (CHY-MAX; Chr. Hansen A/S, Hørsholm, Denmark) diluted 1:50 in acetate buffer ( $\mathrm{pH}$ 5.6) was added, with immediate start of measurement. The Formagraph was run for $30 \mathrm{~min}$ at $32^{\circ} \mathrm{C}$ and the following parameters were measured: rennet clotting time (RCT; min), measured from rennet addition until clotting of the milk started; curd-firming time $\left(\mathbf{k}_{\mathbf{2 0}} ; \mathbf{m i n}\right)$ from the start of clotting until a width of $20 \mathrm{~mm}$ between the curves was achieved; and curd firmness $\left(\mathbf{a}_{30}\right)$, measuring the curd strength after $30 \mathrm{~min}$ as the distance $(\mathrm{mm})$ between the curves. All samples were run in triplicate. Some samples did not coagulate and some coagulated but did not obtain a firmness corresponding to $20 \mathrm{~mm}$ $\left(\mathrm{k}_{20}\right)$. In cases where no coagulation (RCT) occurred, a value of 50 min was given, and samples not achieving $\mathrm{k}_{20}$ were given a value of 40 min according to Devold et al. (2011).

Statistical Analysis. Statistical analyses on milkquality parameters were carried out using a mixedmodel procedure in SAS (version 9.3; SAS Institute Inc., Cary, NC). The model consisted of the following fixed effects: season (EGS and LGS), forage treatment (PC, PR, HH, and HL), period (the period before onset of feeding experiment and the forage treatment period), genotype (E12-00 and E12-01/11), lactation class (1, 2, 3,4 , and 5), and their interactions. The effect of pen within season and forage treatment and the effect of individual goat within season, forage treatment, and pen were included as random effects. Covariation within animal was accounted for in an analysis of repeated measures. The optimal covariance structure was assessed for each parameter with attention to the Akaike information criterion and Schwarz Bayesian criterion (Littell et al., 1998). Orthogonal contrasts were used to separate the effect of season in the period before onset of forage treatment and to separate the effect of season and forage treatment in the forage treatment period. Pearson correlation coefficients were also calculated between some parameters in milk using SAS.

Principal components analysis (PCA) was used to uncover possible relationships among milk components and coagulation properties. Two single partial least squares (PLS) regressions were performed using $\mathrm{a}_{30}$ and $\mathrm{k}_{20}$ as response variables and milk composition as explanatory variables. The categorical factors were set as follows: genotype was set as either 1 or 2 for E1201/11 and E12-00, respectively; grazing season was set as either 1 or 2 for EGS and LGS, respectively; and the feeding treatment was coded as 1,2, 3, and 4 for HH, HL, PC, and PR, respectively. The optimum numbers of factors for the PLS regression models were determined through segment-based cross-validation. The Unscrambler V10.1 and V10.2 software (CAMO Software AS, Oslo, Norway) were used for PCA and PLS regression analyses. Data from 3 goats that suffered from mastitis were removed from all data before statistical analysis.

\section{RESULTS}

\section{Preforage Treatment Period}

Milk composition and rennet coagulation properties of milk from EGS and LGS were analyzed before the goats were assigned to the 4 forage treatments. The results of the preforage treatment period are shown in Table 2.

Milk Composition in the Preforage Treatment Period. The grazing season influenced the milk yield, which was significantly higher $(2.81 \mathrm{~kg} / \mathrm{d})$ in the EGS compared with the LGS $(1.54 \mathrm{~kg} / \mathrm{d})$. Total protein and casein content was lower in the EGS compared with the LGS. The mean size of the casein micelles was smaller in LGS $(201 \mathrm{~nm})$ than in EGS (219 nm), but no major significant differences in content of individual caseins were observed between the seasons. Calcium and magnesium content were higher in milk from goats in the LGS than the EGS. Milk fat and TS content was higher in LGS (46.4 and $120 \mathrm{~g} / \mathrm{kg}$ ) than in EGS $(38.8$ and $110 \mathrm{~g} / \mathrm{kg}$ ). 
Table 2. Milk composition and rennet coagulation properties of goat milk, showing effects of grazing season [early (EGS) and late (LGS)] and genotype [nonhomozygous (E-12-01/11) and homozygous (E12-00) for the deletion in exon 12 encoding CSN1S1] in the preforage treatment period

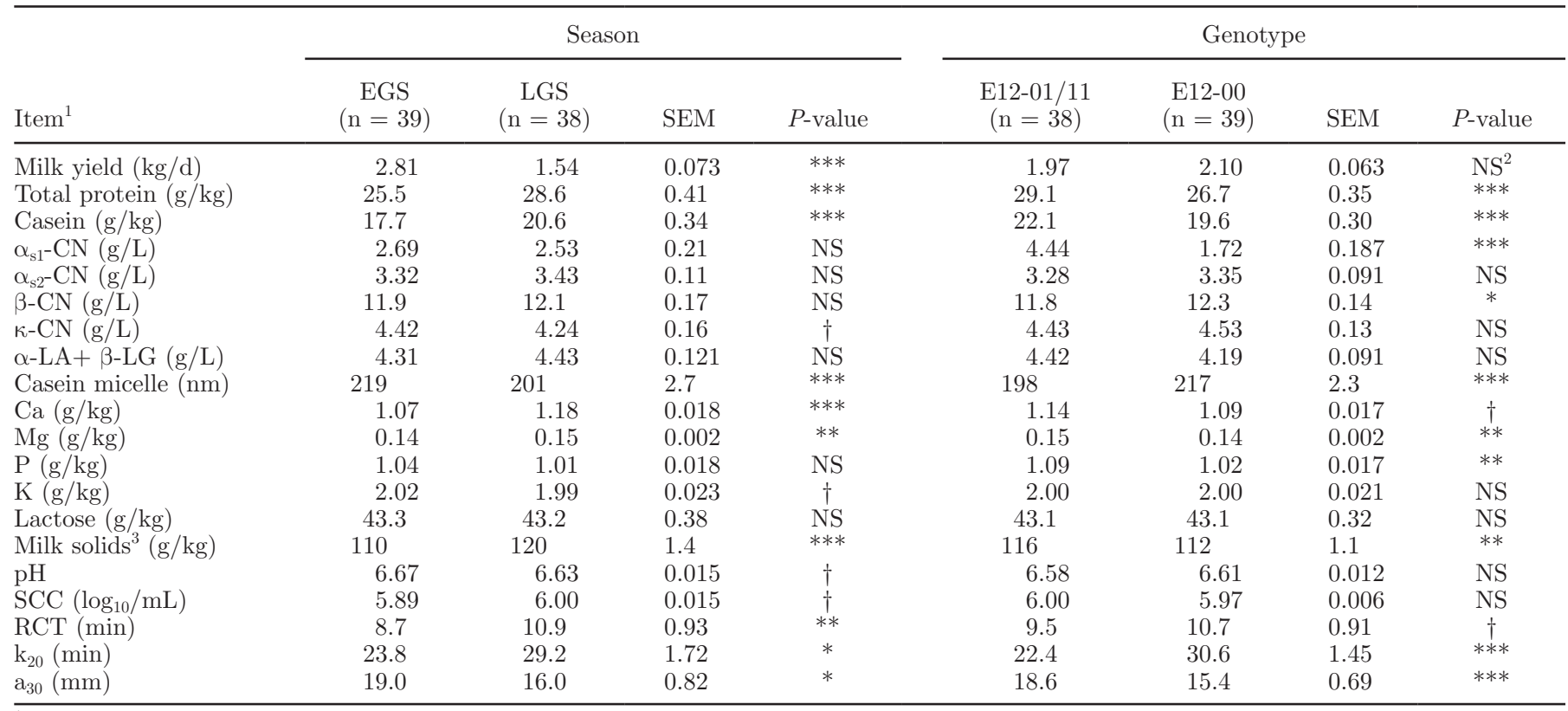

${ }^{1} \mathrm{RCT}=$ rennet clotting time; $\mathrm{k}_{20}=$ curd-firming time; $\mathrm{a}_{30}=$ curd firmness after $30 \mathrm{~min}$.

${ }^{2} \mathrm{NS}=$ nonsignificant at $P>0.10$.

${ }^{3}$ Milk solids is calculated by adding up fat, protein, and lactose concentration.

$\dagger P<0.10 ;{ }^{*} P<0.05 ;{ }^{* *} P<0.01 ;{ }^{* * *} P<0.001$.

Milk from goats homozygous for the deletion in exon 12 (E12-00) had lower protein content (26.7 vs. 29.1 $\mathrm{g} / \mathrm{kg}$ ), casein content (19.6 vs. $22.1 \mathrm{~g} / \mathrm{kg}$ ), TS content (112 vs. $116 \mathrm{~g} / \mathrm{kg}$ ), and larger mean size of the casein micelles $(217 \mathrm{~nm}$ vs. $198 \mathrm{~nm})$ than heterozygous goats or those without defective alleles (E12-01/11). In addition, E12-00 goats also had a lower content of $\alpha_{\mathrm{s} 1} \mathrm{CN}$ $(1.72 \mathrm{~g} / \mathrm{L})$ than milk from E12-01/11 goats $(4.44 \mathrm{~g} / \mathrm{L})$. The content of $\alpha_{\mathrm{s} 1} \mathrm{CN}$ in milk from the E12-00 goats ranged from 0.93 to $5.05 \mathrm{~g} / \mathrm{L}$, whereas the content ranged from 1.74 to $11.13 \mathrm{~g} / \mathrm{L}$ in milk from the E12$01 / 11$ goats. The content of caseins other than $\alpha_{\mathrm{s} 1}-\mathrm{CN}$ was slightly higher in milk from E12-00 goats than from E12-01/11 goats.

Rennet Coagulation Properties. Shorter RCT (8.7 vs.10.9 min), shorter $\mathrm{k}_{20}$ (23.8 vs. $29.2 \mathrm{~min}$ ), and higher $\mathrm{a}_{30}(19.0$ vs. $16.0 \mathrm{~mm})$ were obtained in milk from the EGS compared with milk from the LGS. Milk from E12-00 goats had higher RCT and $\mathrm{k}_{20}(30.6 \mathrm{~min})$ and lower $\mathrm{a}_{30}(15.4 \mathrm{~mm})$ compared with milk from E12$01 / 11$ goats $\left(\mathrm{k}_{20}: 22.4 \mathrm{~min} ; \mathrm{a}_{30}: 18.6 \mathrm{~mm}\right)$, meaning that the latter gave a firmer curd faster.

\section{Forage Experimental Period}

Milk Yield and Composition. As shown in the preforage treatment period (Table 2), goats in the
EGS produced more milk than those in the LGS also during the experimental period (Table 3). The feeding treatments also influenced the milk yield, and the goats on PR had the lowest milk yield in the EGS, whereas goats on HL had the lowest milk yield in the LGS. The contents of total protein $(30.7$ vs. $26.8 \mathrm{~g} / \mathrm{kg} ; P<0.001)$ and casein $(24.2$ vs. $21.0 \mathrm{~g} / \mathrm{kg} ; P<0.001)$ were higher in milk from goats on pasture (PC and $\mathrm{PR}$ ) compared with milk from goats fed hay ( $\mathrm{HH}$ and $\mathrm{HL}$ ), irrespective of grazing season. Milk content of fat (42.6 vs. $34.8 \mathrm{~g} /$ $\mathrm{kg} ; P<0.001)$ and TS $(118$ vs. $107 \mathrm{~g} / \mathrm{kg} ; P<0.001)$ was also higher on pasture than on hay diets. Goats in $\mathrm{HH}$ yielded more milk than goats in $\mathrm{HL}$ in both the EGS and LGS. However, no significant differences existed in milk composition and rennet coagulation properties between milk from the goats receiving the 2 hay treatments.

The milk protein and casein content did not vary within the 2 pasture types or the 2 hay qualities. However, the contents and the proportions of individual caseins were influenced by both grazing season and feeding treatments (Table 4; Figure 2). A significantly higher content and proportion of $\kappa-\mathrm{CN}$ and especially $\alpha_{\mathrm{s} 1}-\mathrm{CN}$ characterized the milk from goats on $\mathrm{PC}$ in both the EGS and LGS (on average, 3.82 and $5.22 \mathrm{~g} / \mathrm{L}$ for $\alpha_{\mathrm{s} 1} \mathrm{CN}$ and $\mathrm{k}-\mathrm{CN}$, respectively) compared with the other treatments. Also, the content and proportion of 
Table 3. Milk yield, milk composition, and rennet coagulation properties in goat milk, showing effects of grazing season [S; early (EGS) and late (LGS)], pasture type [P; cultivated pasture (PC) and rangeland pasture (PR)], and hay quality $[\mathrm{H}$; $\mathrm{HH}=$ high-quality hay $(\mathrm{HH})$ and lowquality hay $(\mathrm{HL})]$

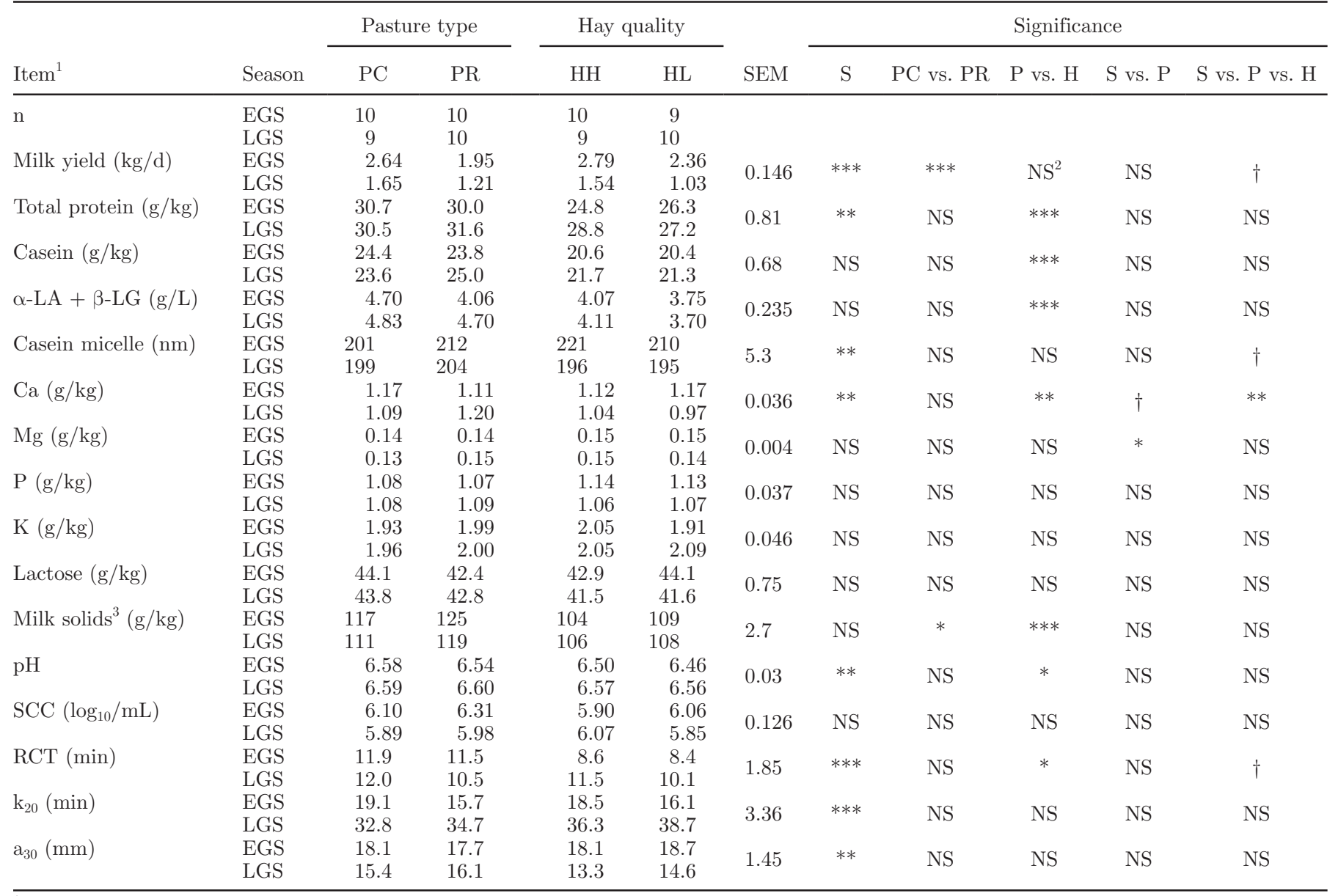

${ }^{1} \mathrm{n}=$ number of goats; $\mathrm{RCT}=$ rennet clotting time; $\mathrm{k}_{20}=$ curd-firming time; $\mathrm{a}_{30}=$ curd firmness after $30 \mathrm{~min}$.

${ }^{2} \mathrm{NS}=$ nonsignificant at $P>0.10$.

${ }^{3}$ Milk solids is calculated by adding up fat, protein, and lactose concentration.

$\dagger P<0.10 ;{ }^{*} P<0.05 ;{ }^{* *} P<0.01 ; * * * P<0.001$.

$\alpha_{\mathrm{s} 2}-\mathrm{CN}$ in milk was influenced by both treatment and season, with higher content in the EGS $(3.68 \mathrm{~g} / \mathrm{L})$ than in the LGS $(2.89 \mathrm{~g} / \mathrm{L})$, and higher in milk from goats on pasture $(3.48 \mathrm{~g} / \mathrm{L})$ than goats fed hay $(3.04 \mathrm{~g} / \mathrm{L})$. The content of $\beta$-CN was higher in the EGS $(12.51 \mathrm{~g} / \mathrm{L})$ than the LGS $(11.54 \mathrm{~g} / \mathrm{L})$ and highest in milk from goats on PR (13.07 g/L and $54.2 \%$ of total casein, respectively) and, on average, higher on pasture $(12.39 \mathrm{~g} / \mathrm{L})$ than on hay (11.66 g/L; Table 4; Figure 2). The pasture effect was stronger in the EGS than in the LGS, as indicated by the significant season versus pasture versus hay contrast. Milk fat (47.7 vs. $37.6 \mathrm{~g} / \mathrm{kg} ; P<0.01)$ and TS $(122$ vs. $114 \mathrm{~g} / \mathrm{kg} ; P<0.05)$ were higher in goats on $\mathrm{PR}$ than those grazing PC. The mean size of the casein micelles was larger in the EGS $(211 \mathrm{~nm})$ compared with the LGS $(199 \mathrm{~nm})$, and negatively correlated with the content of total protein, casein, and $\alpha_{\mathrm{s} 1} \mathrm{CN}$ (Table 5).
The content of milk minerals, except for calcium, was not significantly influenced by the grazing season or feeding treatments. The content of calcium was higher in milk from goats in the EGS compared with the LGS and higher when the goats were fed pasture than hay (Table 3) and positively correlated with the content of $\alpha_{\mathrm{s} 2}-\mathrm{CN}, \beta-\mathrm{CN}$, and lactose (Table 5). The $\mathrm{pH}$ of the milk was slightly higher in the LGS (Table 3).

Rennet Coagulation Properties. Season significantly affected milk coagulation properties (MCP), whereas the effects of feeding treatments were only minor. Season had a large effect on $\mathrm{k}_{20}$, which was almost twice as long in the LGS compared with the EGS (Table 3). In the LGS, very few milk samples achieved the value of $k_{20}$. None of the milk samples from the E12-00 goats obtained $k_{20}$ in the LGS (results not shown). Curd firmness was also affected by graz- 
Table 4. Effect of grazing season [S; early (EGS) and late (LGS)], pasture type [P; cultivated pasture (PC) and rangeland pasture (PR)], and hay quality $[\mathrm{H}$; high-quality hay $(\mathrm{HH})$ and low-quality hay $(\mathrm{HL})]$ on contents of individual caseins $(\mathrm{g} / \mathrm{L})$ in goat milk

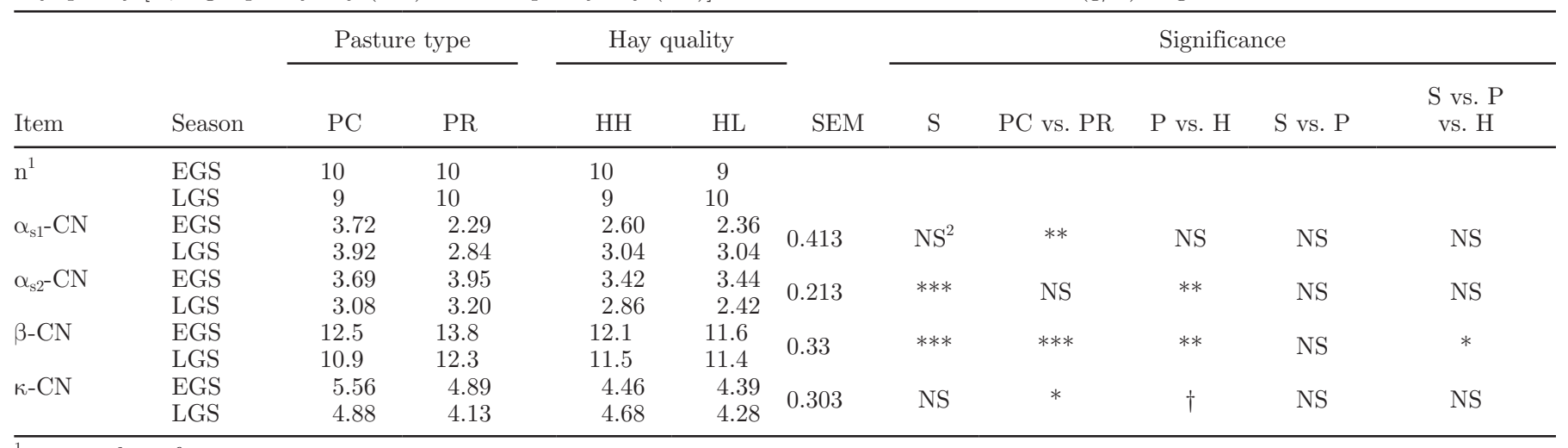

${ }^{1} \mathrm{n}=$ number of goats.

${ }^{2} \mathrm{NS}=$ nonsignificant at $P>0.10$.

$\dagger P<0.10 ;{ }^{*} P<0.05 ;{ }^{* *} P<0.01 ;{ }^{* * *} P<0.001$

ing season: milk from all treatments had reduced $\mathrm{a}_{30}$ in the LGS compared with the EGS (Table 3). Milk from goats fed $\mathrm{HH}$ had the largest reduction (from 18.1 to $13.3 \mathrm{~mm}$ ), whereas milk from goats feed PR had the lowest reduction (from 17.7 to $16.1 \mathrm{~mm}$ ). However, these differences were not significant. Milk from goats on PC and PR had longer RCT compared with milk from goats fed $\mathrm{HH}$ and HL in the EGS, and milk from goats on PC also had the longest RCT in the LGS (Table 3). No significant differences between the feeding treatments on $\mathrm{k}_{20}$ and $\mathrm{a}_{30}$ were observed. A strong negative correlation between $\mathrm{a}_{30}$ and both RCT and $\mathrm{k}_{20}$ was found. Curd firmness was also positively correlated with protein yield and contents of caseins, especially $\alpha_{\mathrm{s} 1^{-}} \mathrm{CN}, \alpha_{\mathrm{s} 2}-\mathrm{CN}$, and $\beta-\mathrm{CN}$, in addition to lactose and calcium content (Table 5).

Multivariate Analysis of Milk Composition and Rennet Coagulation Properties. The PCA of the milk composition and coagulation properties of the samples is presented in Figures 3 and 4. Principal component (PC) 1 and 2 explained $50 \%$ of the variation (Figure 3) and, together with PC 3 (Figure 4), 62\% of the total variation was explained. The relationship between the variables is shown in the correlation loading plot (Figures 3A and 4A), whereas the corresponding score plots (Figures 3B and 4B) show the distribution of the milk samples.

Milk samples of goats in the EGS [Figure 3B, gray (early)] were characterized by higher milk yield, a higher content of $\alpha_{\mathrm{s} 2}-\mathrm{CN}$, calcium, and lactose, in addition to better rennet coagulation properties as higher $\mathrm{a}_{30}$ and shorter $\mathrm{k}_{20}$ compared with milk samples collected in the LGS (black; Figure 3B). The score plot of PC 1 and PC 3 (Figure 4B) separated the milk properties from the hay and pasture treatments in 2 groups. Milk from goats on pasture (PC and PR; gray) was character- ized by a higher content of $\alpha_{\mathrm{s} 2^{-}} \mathrm{CN}, \beta-\mathrm{CN}$, and calcium content compared with milk samples from goats fed hay (HH and HL; black).

Partial least squares regression was used to investigate the influence of milk composition on MCP $\left(a_{30}\right.$ and $\mathrm{k}_{20}$ ). The PLS regression coefficients for $\mathrm{a}_{30}$ and $\mathrm{k}_{20}$ are presented in Figures 5 and 6 , respectively. The content of lactose, calcium, $\alpha_{\mathrm{s}^{2}} \mathrm{CN}, \beta-\mathrm{CN}$, and casein in the goat milk had a significant positive influence on $\mathrm{a}_{30}$, whereas LGS and genotype (deletion in exon 12) had a significant negative influence on $\mathrm{a}_{30}$. The contents of $\alpha_{\mathrm{s}^{-}}, \beta-$, and $\kappa-\mathrm{CN}$ in the milk were significantly negatively correlated with $\mathrm{k}_{20}$, whereas season (LGS) and genotype (E12-00) were positively correlated with $\mathrm{k}_{20}$. As a short time until the achieved $\mathrm{k}_{20}$ is reached is desirable, high contents of $\alpha_{\mathrm{s}^{-}}, \beta-$, and $\kappa-\mathrm{CN}$ are regarded as positive attributes, whereas the LGS and E12-00 then where regarded as negative.

\section{DISCUSSION}

The present study focused on the main hypothesis that ad libitum access to high-quality cultivated pasture would yield higher milk protein and casein content and, thus, improve the MCP compared with milk produced by goats grazing free range in forest pasture. Furthermore, we also expected that the grazing season would not influence MCP and the content of casein and protein in milk from goats grazing PC, but would decline in milk from goats grazing on PR due to decreased forage availability and quality in the latter. A third hypothesis was that the individual casein composition would not be affected by the forage treatment or the grazing season. Two hay qualities were included as control feeds, as hay quality does not change during the course of time as pasture does. As most dairy 
A
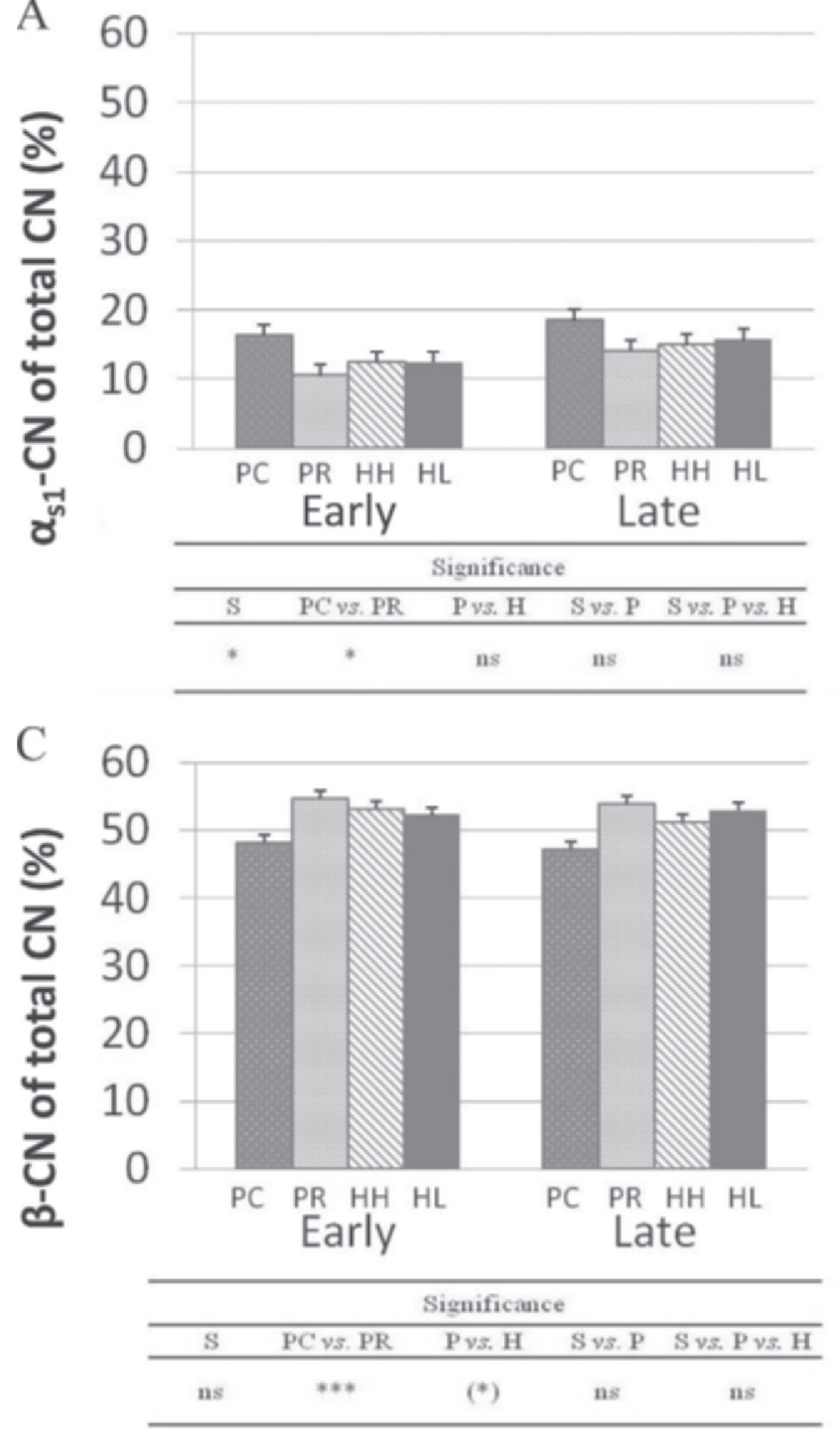

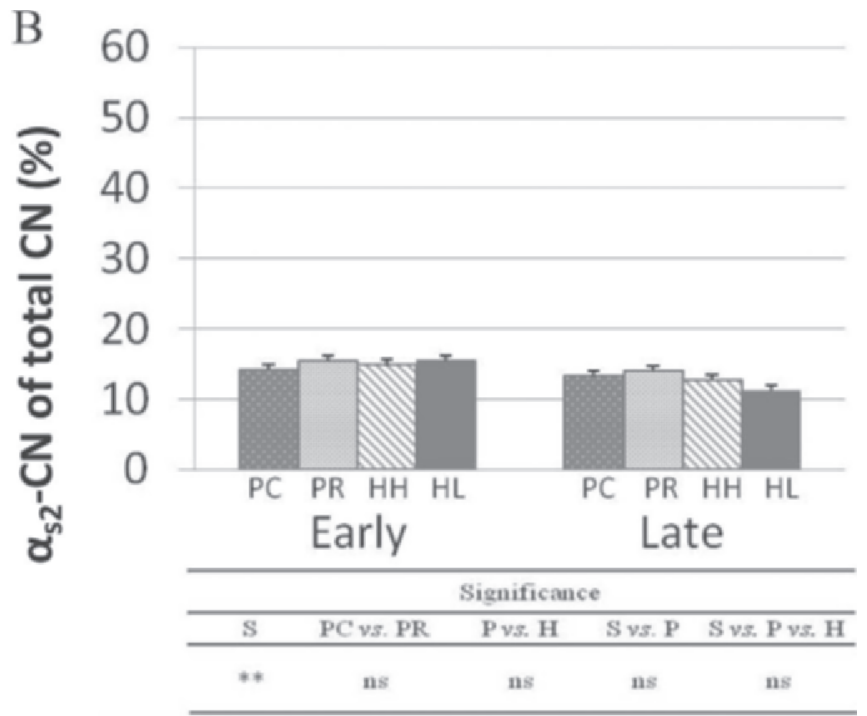

$\mathrm{D}$

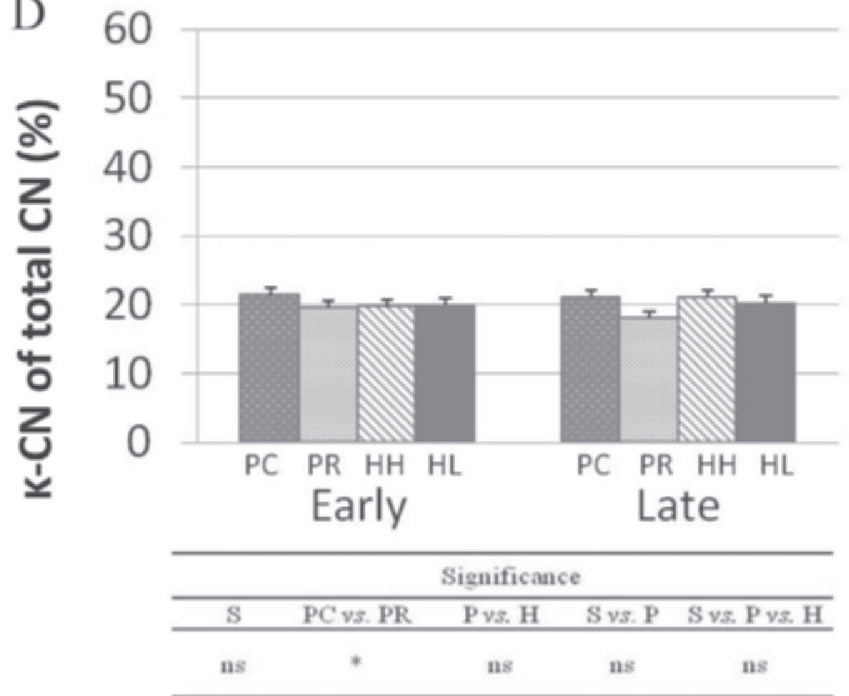

Figure 2. Casein composition of individual caseins (LSM) in goat milk given in percentage of total casein. Effect of grazing season (S; early and late), forage [pasture $(\mathrm{P}) ; \mathrm{PC}=$ cultivated pasture; $\mathrm{PR}=$ rangeland pasture], and hay $(\mathrm{H} ; \mathrm{HH}=$ high-quality hay; HL = low-quality hay). (A) Proportion of $\alpha_{\mathrm{s} 1}-\mathrm{CN}$; (B) proportion of $\alpha_{\mathrm{s} 2}-\mathrm{CN}$; (C) proportion of $\beta$-CN; (D) proportion of $\kappa$-CN. Error bars represent the SEM. ns $=$ nonsignificant at $P>0.10 ;(*)=P<0.10 ;^{*}=P<0.05 ;{ }^{* *}=P<0.01 ; * * *=P<0.001$.

goat farmers in Norway depend on pastures as a feed resource and as mating and kidding season are easily manipulated, our findings have considerable applied relevance.

Our results revealed a higher milk yield in the EGS than in the LGS. Milk yield was $38 \%$ reduced in the LGS compared with the EGS in the 2 grazing treatments. In the $\mathrm{HH}$ and HL treatments, the reduction in milk yield from the EGS to LGS was 45 and $56 \%$, respectively. This may be partially explained by the preforage treatment feeding regimen and by the season itself. The seasonal effect was confounded by the preforage treatment feeding regimen, as the goats in the EGS went directly from indoor silage to the forage experimental period, whereas the goats in the LGS were out on rangeland pasture for about $50 \mathrm{~d}$ before they were allocated to their respective forage treatments. Ideally, the LGS goats should have been kept indoors on silage from the start of lactation until the start of the forage treatment experiment. This was not possible for practical reasons, such as silage availability. However, the goats in the EGS and LGS were in same stage of lactation.

Higher contents of protein and casein in milk from goats on pasture than from those on hay diets were probably due to a higher dietary concentrate-to-forage 
Table 5. Pearson correlation coefficients of some goat milk parameters ${ }^{1}$

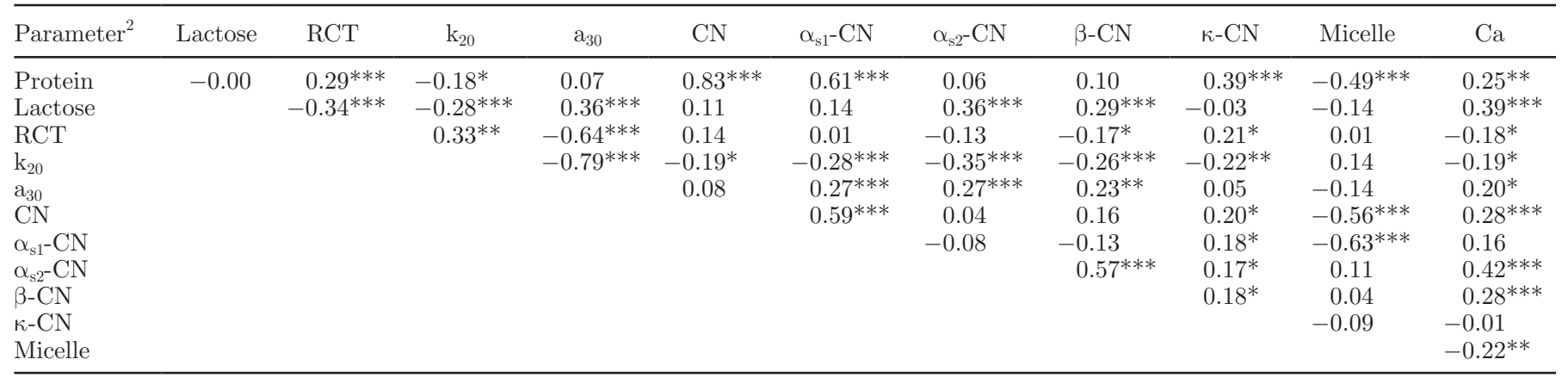

${ }^{1}$ Data from both preforage treatment period and forage experimental period are included $(\mathrm{n}=154)$.

${ }^{2} \mathrm{RCT}=$ rennet clotting time; $\mathrm{k}_{20}=$ curd-firming time; $\mathrm{a}_{30}=$ curd firmness after $30 \mathrm{~min}$; micelle $=$ mean size of casein micelles. ${ }^{*} P<0.05 ;{ }^{* *} P<0.01 ;{ }^{* * *} P<0.001$.

ratio on pasture than on hay (Steinshamn et al., 2014), as increasing energy intake has been shown to have a positive effect on milk protein content (Morand-Fehr and Sauvant, 1980). Likewise, the goats grazing PC spent less energy on locomotion and had more energy available for milk production than the goats grazing on PR. The goats on PR walked, on average, 5.0 and 7.5 $\mathrm{km}$ daily in the EGS and LGS, respectively, whereas the PC was smaller in area and located close to the barn (Steinshamn et al., 2014). Estimated energy balance indicated that goats on PR had lower energy balance (-1.6 MJ of $\mathrm{NE}_{\mathrm{L}} / \mathrm{d}$, on average) than goats on $\mathrm{PC}$ (4.3 MJ of $\mathrm{NE}_{\mathrm{L}} / \mathrm{d}$, on average; Steinshamn et al., 2014).

It is important to establish the factors influencing MCP when the milk is supposed to be used in cheesemaking. In cow milk, the casein composition is known to influence the MCP (St-Gelais and Haché, 2005; Wedholm et al., 2006; Jõudu et al., 2008), but the factors influencing casein composition, except genotype, is less known in both goat and cow milk. In the present study, the composition of individual caseins was influenced both by the feeding treatments and genotype. Particularly interesting was the higher content and proportion of $\alpha_{\mathrm{s} 1^{-}}$and $\kappa-\mathrm{CN}$ in milk from PC compared with the other treatments. A high content and proportion (in total casein) of $k$-CN is desired in cow milk used for cheese production (Wedholm et al., 2006; Jõudu et al., $2008)$, whereas goats with low synthesis of $\alpha_{\mathrm{s} 1}-\mathrm{CN}$ is known to produce milk with reduced MCP (Ambrosoli et al., 1988; Zullo et al., 2005; Devold et al., 2011). Milk from goats in the EGS grazing PR had a high content of $\kappa-\mathrm{CN}$, but apart from longer RCT, a clear positive effect of an increased content of $\kappa-\mathrm{CN}$ on the MCP was difficult to observe. Milk from goats on PR had the highest content and proportion of $\beta-\mathrm{CN}$, irrespective of season. Enrichment with $\beta$-CN powder reduced MCP in cow milk (St-Gelais and Haché, 2005). In goat milk, an increased proportion of $\beta-\mathrm{CN}$ could be associated with reduced MCP, because a reduction in $\alpha_{\mathrm{s} 1} \mathrm{CN}$ was partly compensated by the other caseins and especially $\beta-\mathrm{CN}$. Thus, the reduced MCP is more likely to be caused by a reduced content of $\alpha_{\mathrm{s} 1}$ - $\mathrm{CN}$ rather than by the increased content of $\beta-\mathrm{CN}$ (or by a combined effect). A high proportion of $\alpha_{\mathrm{s} 2}$ - $\mathrm{CN}$ has been reported to be associated with noncoagulating cow milk in an Estonian study (Jõudu et al., 2008); however, our results showed a positive influence of $\alpha_{\mathrm{s}^{2}} \mathrm{CN}$ on $\mathrm{k}_{20}$ and $\mathrm{a}_{30}$. The correlation between the content of $\alpha_{\mathrm{s} 2}-\mathrm{CN}$ and the curd-firming properties of goat milk during coagulation has not, to our knowledge, been reported previously. Milk from goats grazing pasture (PC and $\mathrm{PR}$ ) had a higher content of $\alpha_{\mathrm{s}^{2}}-\mathrm{CN}$ than those fed hay ( $\mathrm{HH}$ and HL). In the LGS, milk from all treatments had lower relative amounts of $\alpha_{\mathrm{s} 2}-\mathrm{CN}$ and higher relative amounts of $\alpha_{\mathrm{s} 1}-\mathrm{CN}$ compared with the EGS season. The effect of diet on the casein content has been referred to in other studies [e.g., Bonanno et al. (2013) and Valenti et al. (2012)] that reported higher milk yield and casein content in milk from goats fed a high-energy diet. Valenti et al. (2012) studied the interaction between genotype and diet and reported a higher daily production [milk yield $\times \alpha_{\mathrm{s} 1}-\mathrm{CN}\left(\mathrm{g} / \mathrm{kg}\right.$ of milk)] of $\alpha_{\mathrm{s} 1}-\mathrm{CN}$ when the goats homozygous for the strong allele (AA) were fed a high-energy diet than if goats homozygous for the weak allele (FF) were fed the same diet. However, the concentration of $\alpha_{\mathrm{s} 1}-\mathrm{CN}$ in milk $(\mathrm{g} / \mathrm{kg})$ and the relative amount of the individual caseins (in total casein) were not significantly different, in contrast to the present study. Apart from the study of Valenti et al. (2012), a dietary effect on the caprine casein composition has not, to our knowledge, been reported previously. A few studies have been conducted on this subject with dairy cows, where it has been shown that the $\kappa-\mathrm{CN}$ proportion in the total casein is adversely affected by poor energy supply (Christian et al., 1999; Coulon et al., 2001; Leiber et al., 2005) and higher content of $\kappa$ - and 
A
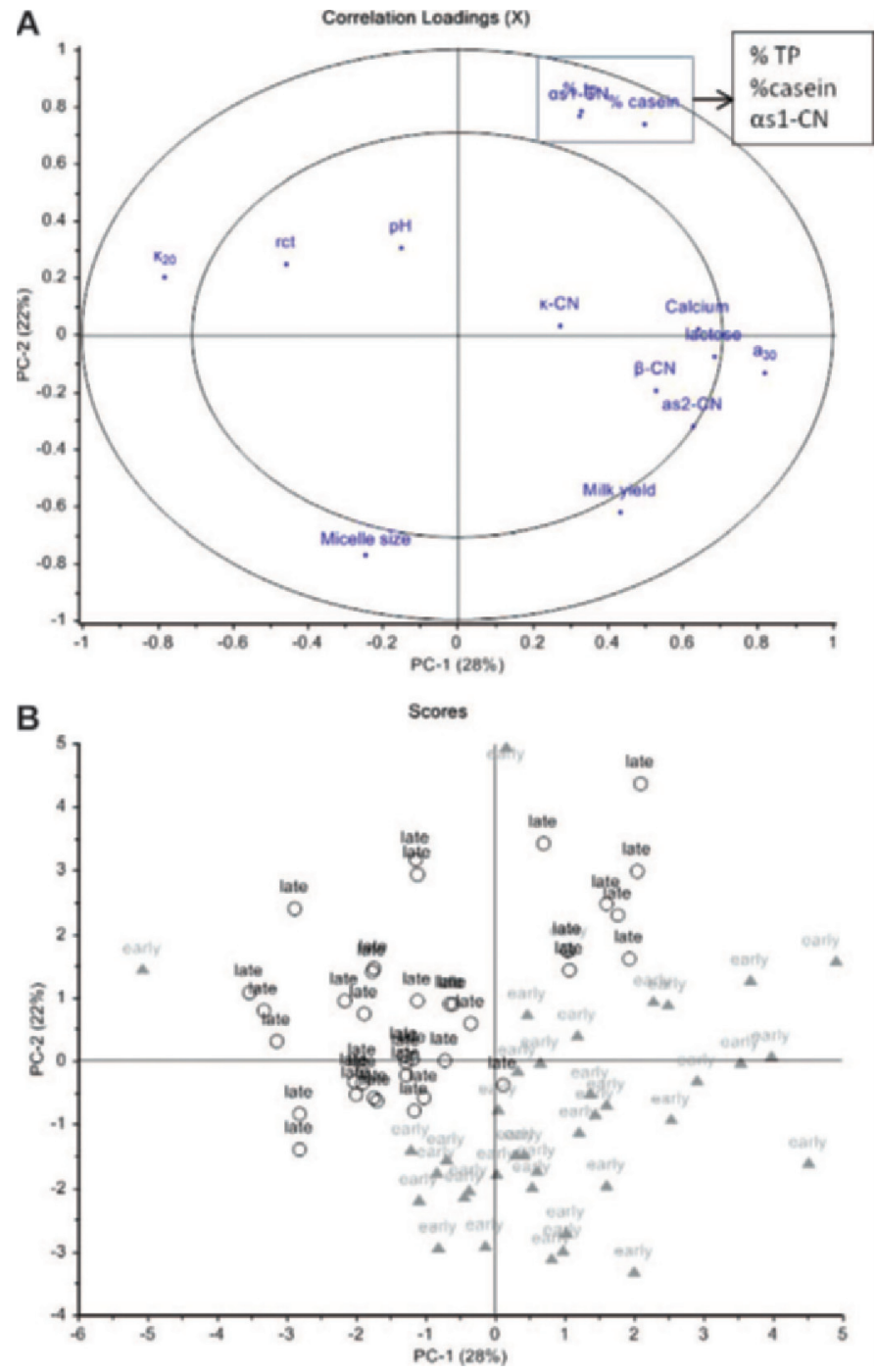

Figure 3. Principal components (PC) analysis of milk composition and rennet coagulation properties in relation to grazing season (PC-1 and PC-2). (A) Correlation loading plot of variables; (B) score plot. Samples are grouped according to season: 1 (gray) = early; 2 (black) $=$ late $\mathrm{TP}=$ total protein $; \mathrm{rct}=$ rennet clotting time; $\mathrm{k}_{20}=$ curdfirming time; $\mathrm{a}_{30}=$ curd firmness after $30 \mathrm{~min}$. Color version available in the online PDF.

$\beta-\mathrm{CN}$ has been found in milk produced indoors than on pasture (Stergiadis et al., 2012). In contrast to the results obtained in our study, a lower content of $\alpha_{\mathrm{s} 1^{-}}$ $\mathrm{CN}$ was observed in milk from cows fed a high-energy pasture diet (Christian et al., 1999). Jõudu et al. (2009) reported that cow milk obtained a stronger curd when the proportion of $\alpha_{\mathrm{s} 2^{-}}$and $\beta-\mathrm{CN}$ in total casein was lower or the ratio of $\kappa-\mathrm{CN}$ to other caseins was higher. A high content of $\alpha_{\mathrm{s}^{2}}-\mathrm{CN}$ and low content of $\kappa-\mathrm{CN}$ were associated with poor- or noncoagulating milk, which is in accordance with the results of Wedholm et al. (2006), who also found a correlation between content
A
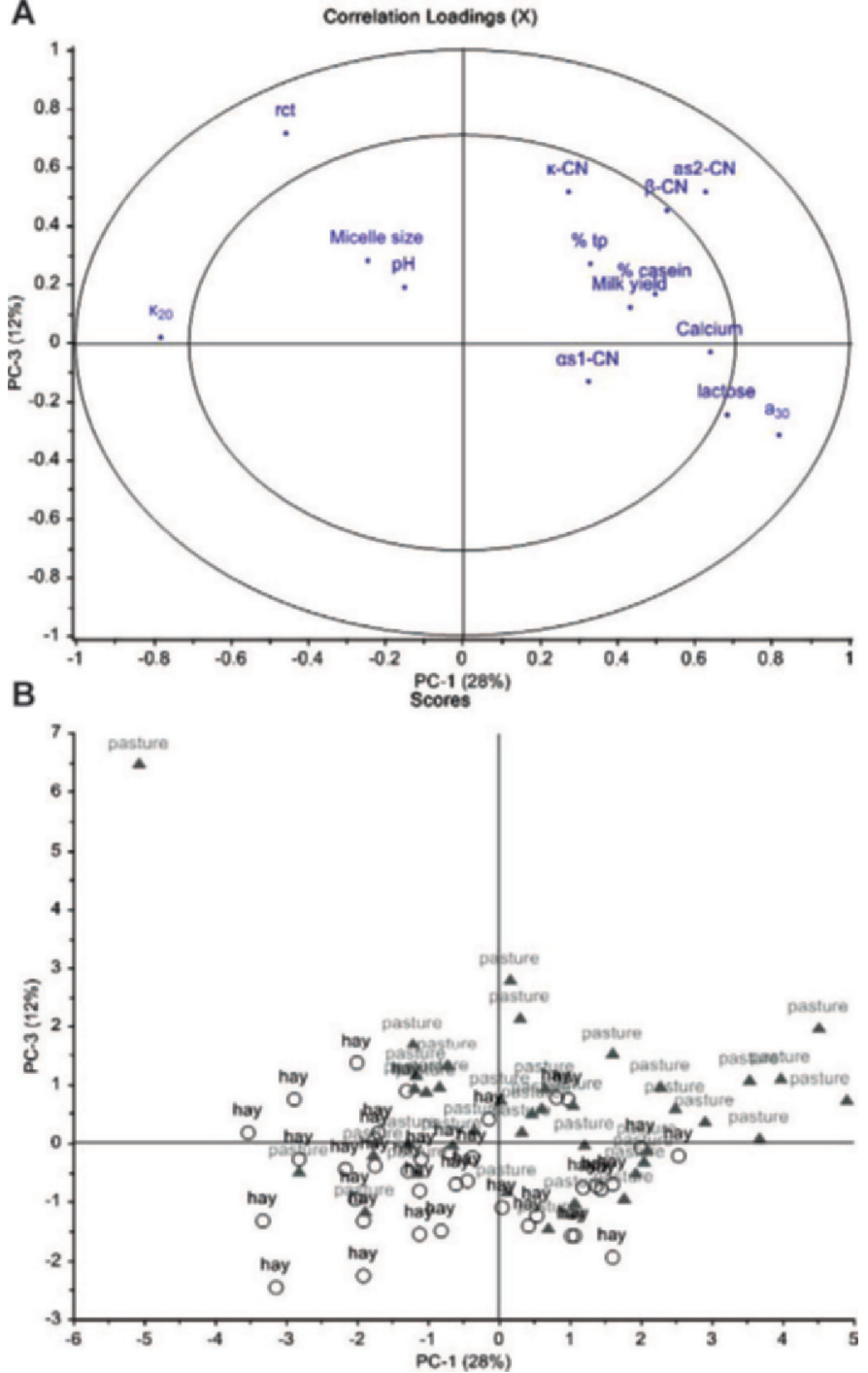

Figure 4. Principal components (PC) analysis of milk composition and rennet coagulation properties in relation to forage type (PC-1 and PC-3). (A) Correlation loading plot of variables; (B) score plot. Samples are grouped according to forage. Black = hay [high-quality hay $(\mathrm{HH})$ and low-quality hay $(\mathrm{HL})]$; gray = pasture [cultivated pasture $(\mathrm{PC})$ and rangeland pasture $(\mathrm{PR})] . \mathrm{tp}=$ total protein; rct $=$ rennet clotting time; $\mathrm{k}_{20}=$ curd-firming time; $\mathrm{a}_{30}=$ curd firmness after 30 min. Color version available in the online PDF.

and proportion of $\kappa-\mathrm{CN}$ and poor or noncoagulating milk. Unfortunately, the latter study did not report the content of $\alpha_{\mathrm{s} 2}$-CN.

Despite a higher protein and casein content (except PC), milk from goats in the LGS displayed poorer rennet coagulation properties by showing a longer $\mathrm{k}_{20}$ and a lower $a_{30}$. Glantz et al. (2010) reported higher $a_{30}$ when the casein micelles were small in size (cow milk), but this relationship between $\mathrm{a}_{30}$ and micelle size could not be established in our study. In general, the mean casein micelle size is negatively correlated with 


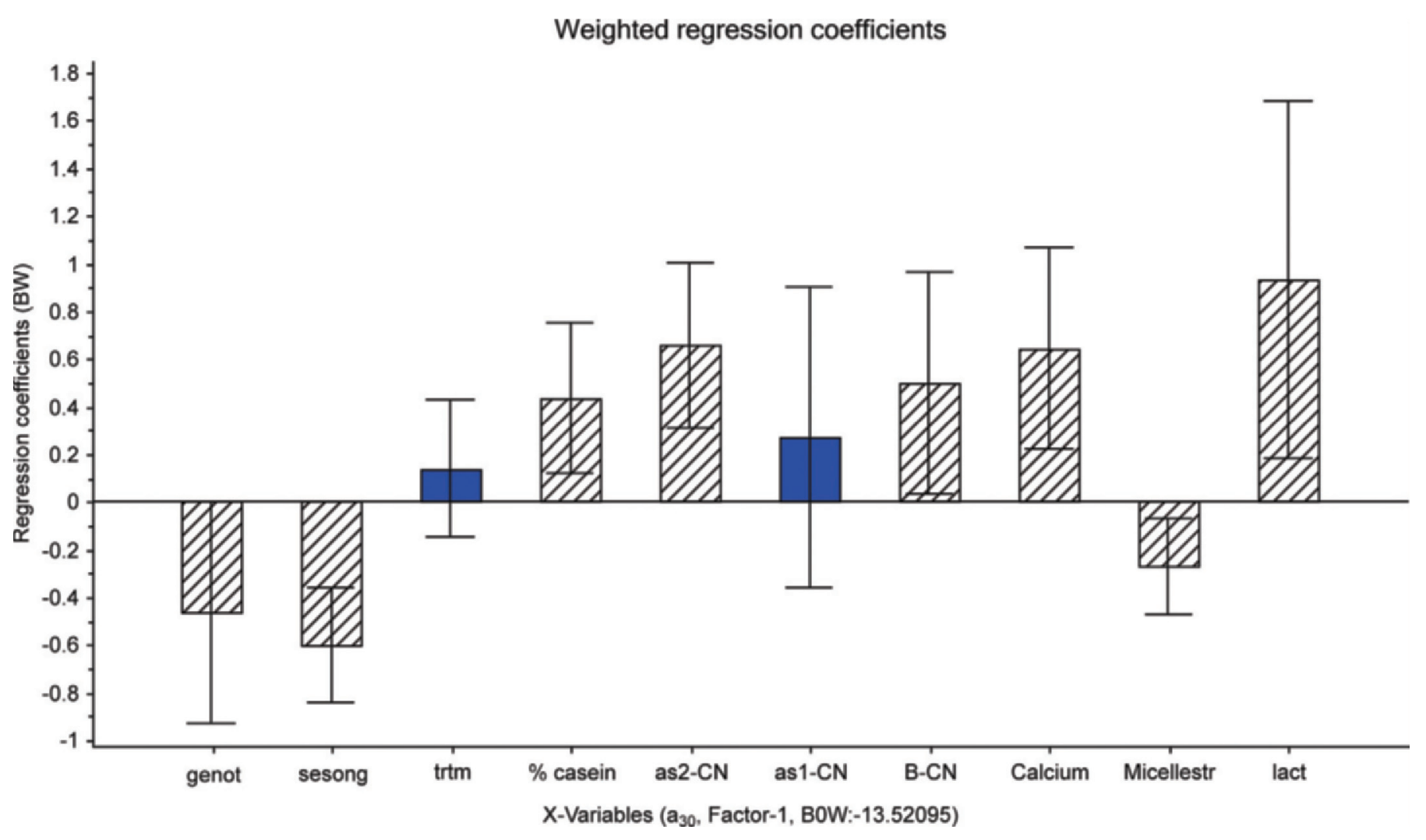

Figure 5. Partial least squares regression coefficients for some selected factors and their influence on curd firmness $\left(\mathrm{a}_{30}\right)$ in goat milk. Striped bars show significant factors for $\mathrm{a}_{30}$. The error bars represent the uncertainty limits of the regression coefficients. genot $=$ genotype; sesong $=$ season; trtm = treatment; Micellestr = micelle size; lact $=$ lactose; $\mathrm{B} 0 \mathrm{~W}=$ regression coefficient of the intercept. Color version available in the online PDF.

the content of $\kappa$-CN (Dalgleish et al., 1989); however, in the current study, the size of the casein micelles were not negatively correlated with the content of $\kappa-\mathrm{CN}$ but with the content of $\alpha_{\mathrm{s} 1}-\mathrm{CN}$. This result is in accordance with earlier studies on goat milk (Pierre et al., 1998; Devold et al., 2011), and may explain the smaller mean size of the casein micelles in the LGS, as the content and proportion of $\alpha_{\mathrm{s} 1}$-CN were higher for all treatments in this season. As expected, goats homozygous for the deletion in exon 12 (E12-00) had poorer MCP compared with goats having 1 or 2 nondefective alleles (E12-01/11). The longer $\mathrm{k}_{20}$ and lower $\mathrm{a}_{30}$ are in accordance with previous Norwegian studies (Devold et al., 2011) and has also been reported for weak alleles in other breeds (e.g., Cilentana; Zullo et al., 2005) and Saanen and Alpine (Ambrosoli et al., 1988). However, we did not expect the content of $\alpha_{\mathrm{s} 1}$-CN in milk from of the E12-00 goats to vary in the range of 0.93 to 5.05 $\mathrm{g} / \mathrm{L}$. In fact, these goats seem not to have been "true null," as indicated in previous studies (Vegarud et al., 1999; Devold et al., 2011), even though the content of $\alpha_{\mathrm{s} 1} \mathrm{CN}$ was extremely low compared with strong genotypes such as, for example, Ethiopian goats (Mes- tawet et al., 2013) and Girgentana goats (Valenti et al., 2012). Because the frequency of the defective allele encoding $\alpha_{\mathrm{s} 1}$-CN has been very high $(0.73)$ in the Norwegian goat population (Hayes et al., 2006), different casein compositions in milk related to feeding pasture and hay in the present study were very interesting. Goats grazing PC increased their content of $\alpha_{s 1}-\mathrm{CN}$ in milk, independently of genotype; however, the effect of increased $\alpha_{\mathrm{s} 1}-\mathrm{CN}$ in the milk did not affect the MCP notably. This observation could imply that also other factors are important for MCP. The protein that may be the most important regarding MCP seems to be $\alpha_{\mathrm{s} 2}-\mathrm{CN}$, as the content of this protein was lower in milk from all feeding groups in the LGS, in a similar pattern as $\mathrm{a}_{30}$. Milk from goats grazing PR had the smallest reduction in $\mathrm{a}_{30}$ from the EGS to LGS, and this milk also had the highest content of $\alpha_{\mathrm{s} 2}-\mathrm{CN}$. A reduction in the calcium content was observed in milk from all treatments except PR in the LGS. Calcium is, in addition to hydrophobic interactions, important for the interactions between and within the casein molecules and the casein micelles and is, therefore, correlated with $\mathrm{a}_{30}$. The content of lactose was also correlated with $\mathrm{a}_{30}$, as 


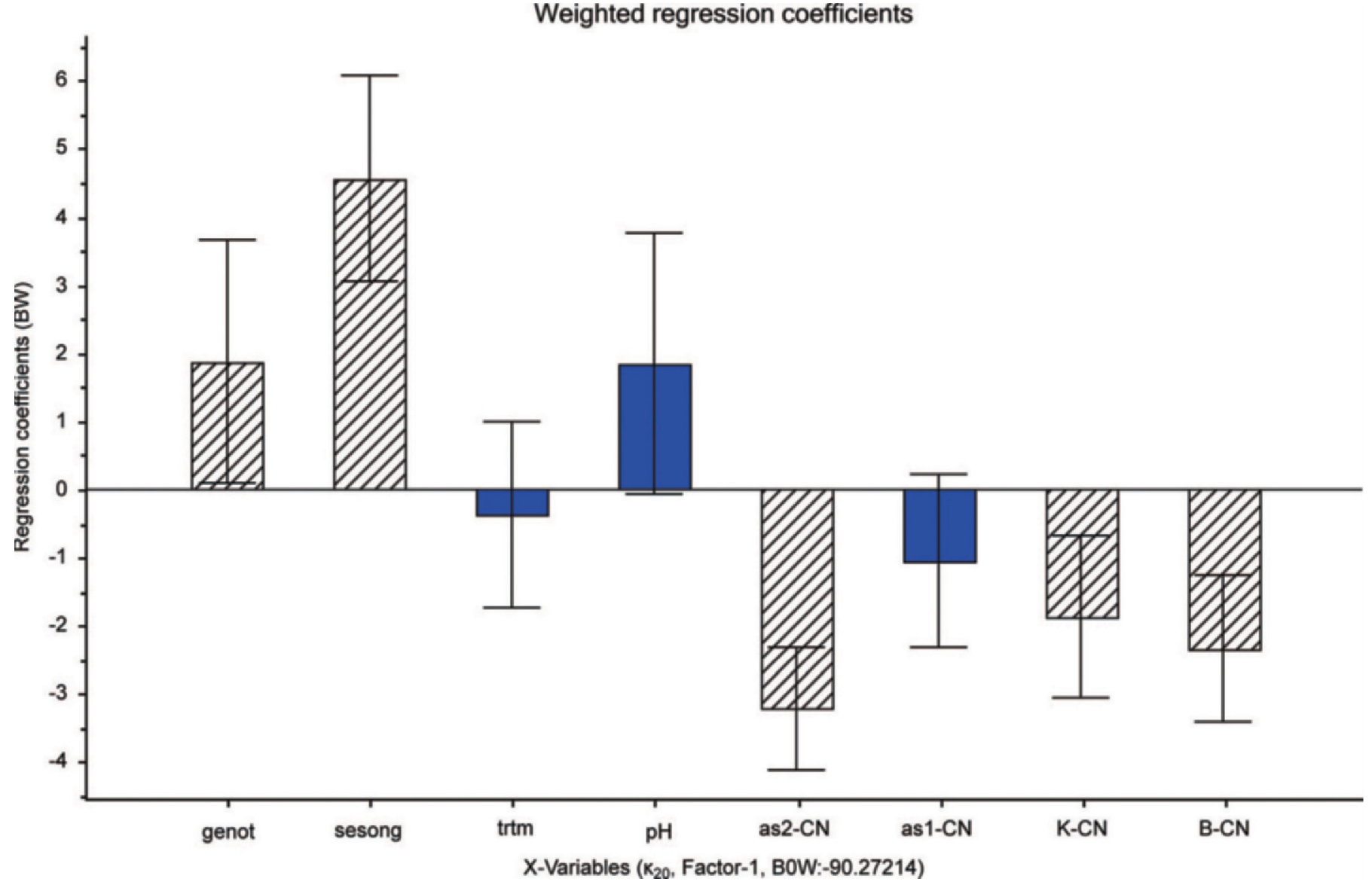

Figure 6. Partial least squares regression coefficients for some selected factors and their influence on firming time $\left(\mathrm{k}_{20}\right)$ in goat milk. Striped bars show significant factors for $\mathrm{k}_{20}$. The error bars represent the uncertainty limits of the regression coefficients. genot $=$ genotype; sesong $=$ season; trtm = treatment; $\mathrm{B} 0 \mathrm{~W}=$ regression coefficient of the intercept. Color version available in the online PDF.

also shown by others (Superchi et al., 2005; Todaro et al., 2005; Leitner et al., 2011; Pazzola et al., 2012); however, it is not likely that the lactose content itself improves $\mathrm{a}_{30}$. The connection between the content of lactose and the $\mathrm{a}_{30}$ and $\mathrm{k}_{20}$ is probably an indicator of an unexplained correlation.

The variation in $\mathrm{a}_{30}$ between the individual goat milk samples ranged from 0 to $30 \mathrm{~mm}$, and even for the E12-01/00 goats, the majority of samples had a lower $\mathrm{a}_{30}$ compared with what has been reported in the literature. An average $\mathrm{a}_{30}$ of $25 \mathrm{~mm}$ has been reported for milk from Girgentana goats (Todaro et al., 2005). The highest $\mathrm{a}_{30}$ ever reported for goat milk was probably shown by Mestawet et al. (2013), who observed an $\mathrm{a}_{30}$ of $45 \mathrm{~mm}$ in milk from a local Ethiopian breed. The reason for the reduced curd-firming properties in the LGS warrants further investigation, as the differences in milk components measured in the current study hardly can explain the impaired curd-firming properties completely. Degradation of caseins by plasmin may infer the $\mathrm{a}_{30}$ and reduce the cheese yield (Bastian and Brown, 1996). In addition to impaired MCP, the milk yield was reduced in the LGS. Plasmin may cleave off a peptide from $\beta-\mathrm{CN}$ (fragment 1-28) that blocks the $\mathrm{K}^{+}$ channels of the mammary epithelial cells, which is associated with reduced milk yield (Silanikove et al., 2000). A reduction in the content of $\alpha_{\mathrm{s} 2^{-}}$and $\beta-C N$ in the LGS may indicate degradation of these caseins by plasmin, which is known to impair the clotting properties of milk (Fantuz et al., 2001; Leitner et al., 2006). Factors such as stress and late lactation are known to increase the plasmin activity in milk (Silanikove et al., 2000; Fantuz et al., 2001); however, the goats in our experiment were in the same lactation stage in both the EGS and LGS.

Further selection of goats without the deletion in exon 12 (CSN1S1) and selection of goats producing milk with good MCP is important for increasing the milk quality for cheese production. Moreover, pasture increases the content of protein, casein, $\alpha_{\mathrm{s} 1}-\mathrm{CN}, \alpha_{\mathrm{s} 2^{-}}$ $\mathrm{CN}$, and calcium, which influences MCP positively. 


\section{CONCLUSIONS}

The present study showed that milk composition and casein composition were influenced by dietary treatment. Pasture (cultivated and rangeland) increased the casein and protein content in the milk, which is favorable with respect to cheese yield. The casein composition in milk from goats grazing $\mathrm{PC}$ had a high content of $\alpha_{\mathrm{s} 1^{-}}$and $\kappa-\mathrm{CN}$, known to increase the rennet coagulation properties in cow milk. However, the rennet coagulation properties of the milk were not prominently influenced by the feeding treatment, whereas these properties were negatively affected by LGS. Also, milk yield was reduced in the LGS, whereas the content of casein was unchanged. The reason for the reduced milk yield and rennet coagulation properties in the LGS should be further investigated.

\section{ACKNOWLEDGMENTS}

This project was financially supported by The Norwegian Research Council (Oslo, Norway) and TINE BA (Oslo, Norway). We acknowledge the great help of the staff at Senja videregående skole (Gibostad, Norway) under the direction of Magnhild Johanne Nymo. We are grateful to Irene Comi, May Helene Aalberg, Tor Bruun, and Mestawet Taye Asfaw (all from Norwegian University of Life Sciences, Ås, Norway) for their technical assistance in milk analysis and to Kia Hansen (Arctic University of Norway, Tromsø, Norway) and Rebekka May-Lene Helgesen (Norwegian University of Life Sciences) for technical assistance in the conducting of the feeding experiment. TINE BA is acknowledged for performing milk routine analysis (Fourier-transform infrared spectroscopy) free of charge.

\section{REFERENCES}

Ambrosoli, R., L. di Stasio, and P. Mazzocco. 1988. Content of $\alpha_{\mathrm{s}^{-}}$ casein and coagulation properties in goat milk. J. Dairy Sci. $71: 24-28$.

AOAC (Association of Official Analytical Chemists). 1990. Official Methods of Analysis. 15th ed. AOAC, Arlington, VA.

Aschaffenburg, R., and J. Drewry. 1959. New procedures for the routine determination of the various non-casein proteins of milk. Pages 1631-1637 in Proc. XVth International Dairy Congress. International Dairy Federation, London, UK.

Bastian, E. D., and R. J. Brown. 1996. Plasmin in milk and dairy products: An update. Int. Dairy J. 6:435-457.

Bonanno, A., A. Di Grigoli, A. Di Trana, P. Di Gregorio, G. Tornambè, V. Bellina, S. Claps, G. Maggio, and M. Todaro. 2013. Influence of fresh forage-based diets and $\alpha_{\mathrm{S}_{1} \text {-casein }}(C S N 1 S 1)$ genotype on nutrient intake and productive, metabolic, and hormonal responses in milking goats. J. Dairy Sci. 96:2107-2117.

Chilliard, Y., A. Ferlay, J. Rouel, and G. Lamberet. 2003. A review of nutritional and physiological factors affecting goat milk lipid synthesis and lipolysis. J. Dairy Sci. 86:1751-1770.

Christian, M. P., C. Grainger, B. J. Sutherland, J. J. Mayes, M. C. Hannah, and B. Kefford. 1999. Managing diet quality for Cheddar cheese manufacturing milk. 2. Pasture v. grain supplements. J. Dairy Res. 66:357-363.

Clark, S., and J. W. Sherbon. 2000. $\alpha_{\mathrm{s} 1}$-Casein, milk composition and coagulation properties of goat milk. Small Rumin. Res. 38:123134.

Coulon, J.-B., D. Dupont, S. Pochet, P. Pradel, and H. Duployer. 2001. Effect of genetic potential and level of feeding on milk protein composition. J. Dairy Res. 68:569-577.

Dagnachew, B. S., G. Thaller, S. Lien, and T. Ådnøy. 2011. Casein SNP in Norwegian goats: Additive and dominance effects on milk composition and quality. Genet. Sel. Evol. 43:31.

Dalgleish, D. G., D. S. Horne, and A. J. R. Law. 1989. Size-related differences in bovine casein micelles. Biochim. Biophys. Acta 991:383-387.

Devold, T., R. Nordb $\varnothing$, T. Langsrud, C. Svenning, M. Brovold, E. S $\varnothing-$ rensen, B. Christensen, T. Ådnøy, and G. Vegarud. 2011. Extreme frequencies of the $\alpha_{\mathrm{s1}}$-casein "null" variant in milk from Norwegian dairy goats-Implications for milk composition, micellar size and renneting properties. Dairy Sci. Technol. 91:39-51.

Devold, T. G., M. J. Brovold, T. Langsrud, and G. E. Vegarud. 2000. Size of native and heated casein micelles, content of protein and minerals in milk from Norwegian Red Cattle-Effect of milk protein polymorphism and different feeding regimes. Int. Dairy J. 10:313-323.

Eknæs, A., and S. Skeie. 2006. Effect of different level of roughage availability and contrast levels of concentrate supplementation on flavour of goat milk. Small Rumin. Res. 66:32-43.

Fantuz, F., F. Polidori, F. Cheli, and A. Baldi. 2001. Plasminogen activation system in goat milk and its relation with composition and coagulation properties. J. Dairy Sci. 84:1786-1790.

Glantz, M., T. G. Devold, G. E. Vegarud, H. Lindmark Månsson, H. Stålhammar, and M. Paulsson. 2010. Importance of casein micelle size and milk composition for milk gelation. J. Dairy Sci. 93:1444-1451.

Gómez-Ruiz, J. Á., B. Miralles, P. Agüera, and L. Amigo. 2004. Quantitative determination of $\alpha_{\mathrm{s} 2^{-}}$and $\alpha_{\mathrm{s} 1^{-}}$-casein in goat's milk with different genotypes by capillary electrophoresis. J. Chromatogr. A $1054: 279-284$.

Hayes, B., N. Hagesæther, T. Ådnøy, G. Pellerud, P. R. Berg, and S. Lien. 2006. Effects on production traits of haplotypes among casein genes in Norwegian goats and evidence for a site of preferential recombination. Genetics 174:455-464.

Jenness, R., and J. Koops. 1962. Preparation and properties of a salt solution which simulates milk ultrafiltrate. Neth. Milk Dairy J. $16: 153-164$.

Jõudu, I., M. Henno, T. Kaart, T. Püssa, and O. Kärt. 2008. The effect of milk protein contents on the rennet coagulation properties of milk from individual dairy cows. Int. Dairy J. 18:964-967.

Jõudu, I, M Henno, S Värv, H Viinalass, T Püssa, T Kaart, D Arney, and O. Kärt. 2009. The effect of milk proteins on milk coagulation properties in Estonian dairy breeds. Veterinarija ir Zootechnika 46:14-19.

Leiber, F., D. Nigg, C. Kunz, M. R. Scheeder, H.-R. Wettstein, and M. Kreuzer. 2005. Protein composition, plasmin activity and cheesemaking properties of cows' milk produced at two altitudes from hay of lowland and high-alpine origins. J. Dairy Res. 72:65-74.

Leitner, G., O. Krifucks, U. Merin, Y. Lavi, and N. Silanikove. 2006. Interactions between bacteria type, proteolysis of casein and physico-chemical properties of bovine milk. Int. Dairy J. 16:648-654.

Leitner, G., U. Merin, and N. Silanikove. 2011. Effects of glandular bacterial infection and stage of lactation on milk clotting parameters: Comparison among cows, goats and sheep. Int. Dairy J. 21:279-285.

Littell, R. C., P. R. Henry, and C. B. Ammerman. 1998. Statistical analysis of repeated measures data using SAS procedures. J. Anim. Sci. 76:1216-1231.

Lunnan, T., and J. Todnem. 2011. Forage quality of native grasses in mountain pastures of southern Norway. Pages 568-570 in Grassland Farming and Land Management Systems in Mountainous Regions. Proceedings of the 16th Symposium of the European Grassland Federation. E. Pötsch, B. Krautzer, and A. Hopkins, ed. 
Agricultural Research and Education Centre (AREC), RaumbergGumpenstein, Irdning, Austria.

Marletta, D., A. Criscione, S. Bordonaro, A. M. Guastella, and G. D'Urso. 2007. Casein polymorphism in goat's milk. Lait 87:491504.

Mayes, R. W., C. S. Lamb, and P. M. Colgrove. 1986. The use of dosed and herbage n-alkanes as markers for the determination of herbage intake. J. Agric. Sci. 107:161-170.

McMahon, D. J., and R. J. Brown. 1982. Evaluation of Formagraph for comparing rennet solutions. J. Dairy Sci. 65:1639-1642.

Mestawet, T. A., A. Girma, T. Ådnøy, T. G. Devold, and G. E. Vegarud. 2013. Newly identified mutations at the CSN1S1 gene in Ethiopian goats affect casein content and coagulation properties of their milk. J. Dairy Sci. 96:4857-4869.

Morand-Fehr, P., and D. Sauvant. 1980. Composition and yield of goat milk as affected by nutritional manipulation. J. Dairy Sci. 63:1671-1680.

NRC. 2001. Nutrient Requirements of Dairy Cattle. 7th rev. ed. National Academy Press, Washington, DC.

Pazzola, M., F. Balia, V. Carcangiu, M. L. Dettori, G. Piras, and G. M. Vacca. 2012. Higher somatic cells counted by the electronic counter method do not influence renneting properties of goat milk. Small Rumin. Res. 102:32-36.

Pearse, A. G. E. 1980. Histochemistry, Theoretical and Applied: Preparative and Optical Technology. Churchill Livingstone, London, UK.

Pierre, A., F. Michel, Y. Le Graët, and L. Zahoute. 1998. Casein micelle size in relation with casein composition and $\alpha_{\mathrm{s} 1}, \alpha_{\mathrm{s} 2}, \beta$ and $\kappa$ casein contents in goat milk. Lait 78:591-605.

Silanikove, N., A. Shamay, D. Shinder, and A. Moran. 2000. Stress down regulates milk yield in cows by plasmin induced $\beta$-casein product that blocks $\mathrm{K}^{+}$channels on the apical membranes. Life Sci. 67:2201-2212.

Skeie, S. B. 2010. Milk quality requirements for cheesemaking. Pages 433-453 in Improving the Safety and Quality of Milk. M. Griffiths, ed. Woodhead Publishing, Cambridge, UK.

St-Gelais, D., and S. Haché. 2005. Effect of $\beta$-casein concentration in cheese milk on rennet coagulation properties, cheese composition and cheese ripening. Food Res. Int. 38:523-531.
Steinshamn, H., R. A. Inglingstad, D. Ekeberg, J. Mølmann, and M. Jørgensen. 2014. Effect of forage type and season on Norwegian dairy goat milk production and quality. Small Rumin. Res. (Accepted).

Stergiadis, S., C. Leifert, C. J. Seal, M. D. Eyre, J. H. Nielsen, M. K. Larsen, T. Slots, H. Steinshamn, and G. Butler. 2012. Effect of feeding intensity and milking system on nutritionally relevant milk components in dairy farming systems in the North East of England. J. Agric. Food Chem. 60:7270-7281.

Superchi, P., A. Summer, A. Sabbioni, M. Malacarne, P. Franceschi, and P. Mariani. 2005. Feeding management and production factors affecting goat milk composition and quality. I. Titratable acidity and rennet-coagulation. Pages 219-225 in Proc. 11th FAO CIHEAM Network on Sheep and Goat Nutrition Options Méditerranéennes, Series A. Accessed Mar. 26, 2014. http://om.ciheam. org/article.php?IDPDF $=800383$.

Todaro, M., M. L. Scatassa, and P. Giaccone. 2005. Multivariate factor analysis of Girgentana goat milk composition. Ital. J. Anim. Sci. 4:403-410.

Valenti, B., R. I. Pagano, and M. Avondo. 2012. Effect of diet at different energy levels on milk casein composition of Girgentana goats differing in CSN1S1 genotype. Small Rumin. Res. 105:135-139.

Van Soest, P. J., J. B. Robertson, and B. A. Lewis. 1991. Methods for dietary fiber, neutral detergent fiber, and nonstarch polysaccharides in relation to animal nutrition. J. Dairy Sci. 74:3583-3597.

Vegarud, G. E., T. G. Devold, R. Opheim, E. Loeding, C. Svenning, R. K. Abrahamsen, S. Lien, and T. Langsrud. 1999. Genetic variants of Norwegian goats milk composition, micellar size and renneting properties. Int. Dairy J. 9:367-368.

Wedholm, A., L. B. Larsen, H. Lindmark-Månsson, A. H. Karlsson, and A. Andrén. 2006. Effect of protein composition on the cheesemaking properties of milk from individual dairy cows. J. Dairy Sci. 89:3296-3305.

Zullo, A., C. M. A. Barone, L. Chianese, P. Colatruglio, M. Occidente, and D. Matassino. 2005. Protein polymorphisms and coagulation properties of Cilentana goat milk. Small Rumin. Res. 58:223-230. 